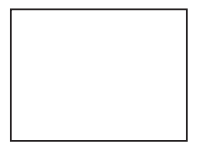

UNIVERSITY OF THE AEGEAN

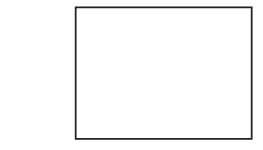

KATHOLIEKE UNIVERSITEIT LEUVEN

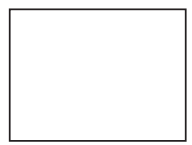

UNIVERSITÉ CATHOLIQUE DE LOUVAIN

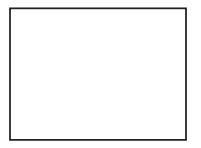

UNIVERSITY OF COPENHAGEN

\title{
5th Conference in Actuarial Science \& Finance on Samos, September 4-7, 2008
}

The Department of Statistics \& Actuarial-Financial Mathematics of University of the Aegean is pleased to host the $5^{\text {th }}$ Samos Conference. Detailed information can be found on the web site:

\section{http://www.actuar.aegean.gr/samos2008/}

This event, jointly organized with the Katholieke Universiteit Leuven, the Université Catholique de Louvain and the Københavns Universitet, provides a forum for state-of-the-art results and the latest advances in the area of actuarial science and finance. The meeting is open to people from Universities, Insurance Companies, Banks, Consulting Firms or Regulatory Authorities, interested in actuarial-financial mathematics.

\section{TOPICS:}

- Extremes and Large Deviations in Actuarial Science (Chair, H. DreEs)

- Measuring Risk in Non-Life Insurance (Chair, H. SCHMIDLI)

- Integrated Risk Management (Chair, Th. ZARIPHOPOUlOU)

- Modelling Dependence in Multivariate Risk (Chair, G. SAMorodnitsKy)

- Mortality Risk Management in Life, Health, and Pension Insurance (Chair, H. GERBER)

- Risk and Stochastic Control (Chair, S. Asmussen)

\section{INVITED SPEAKERS:}

- Armelle Guillou - University of Strasbourg, France

- Alfred Müller - Heriot-Watt University, United Kingdom

- PATRICK BRocketT - University of Texas at Austin, USA

- JAN ROSINSKI - University of Tennessee, USA

- BIFFIS ENRICO - City University, United Kingdom

- Andreas KyPRIANOU - University of Bath, United Kingdom

- RAMA CONT - Columbia University, USA 
A short course will take place before the conference (September, 1-3) under the title:

- Subexponential Tails in the World of Dependence, by Q. TANG - University of Iowa, USA

\section{SCIENTIFIC COMMITTEE:}

$\begin{array}{lll}\text { Asmussen Soeren } & \text { Konstantinides Dimitrios } & \text { Samorodnitsky Gena } \\ \text { Drees Holger } & \text { Makov Udi } & \text { Steffensen Mogens } \\ \text { Foss Serguei } & \text { Marceau Etienne } & \text { Teugels Jef } \\ \text { Frangos Nicolaos } & \text { Mikosch Thomas } & \text { Verrall Richard } \\ \text { Gerber Hans } & \text { Morettin Pedro } & \text { Zariphopoulou Thaleia } \\ \text { Goovaerts Marc } & \text { Ng Kai Wang } & \\ \text { Guillen Montserrat } & \text { Papaioanou Takis (Chair) } & \end{array}$

